African J. Biol. Sci., 17 (1): 189-203 (2021)

ISSN 1687-4870

e- ISSN 2314-5501 (online)

www.ajbs.journals.ekb.eg

E.mail: aasdjournal@yahoo.com

\title{
Effect of different concentrations and application time of vitamin B12 on antioxidant response of Physiophora alceae
}

Eman A. Abdelfattah

Department of Entomology, Faculty of Science, Cairo University, Cairo, Egypt

eman.alaaeldein@gmail.com

Received: August 4, 2021; Accepted: August 15, 2021; Available online: August 31, 2021

\begin{abstract}
Pharmaceutical waste and food contaminants have direct and indirect effects on quality of life and even ecosystem structure and function. The existence of the ecosystem concept leads to the interaction between living organisms and the environment, where the power distribution capacity can occur and influence the ecological concept such as the food chain, ecological pyramids and the food web. Physiophora alceae is present with vegetable residues and helps in their decomposition. The presence of a decomposing environment may lead to oxidative stress for the insect. There are plenty of exogenous antioxidants that are being used, especially Vitamin B12 to reduce oxidative stress and restore the balance between antioxidants and oxidants in the insect. In this study, the ability of $P$. alceae insects to be used as a bioremediation tool for drug and plant residues as well as to evaluate the use of vitamin B12 in adult $P$. alceae insects to reduce the physiological effects of oxidative stress markers on the insect was examined. Adult $P$. alceae insects were treated with commercial vitamin B12. The first group (250 insects) was treated with different concentrations $(0.125,0.25,0.5,1 \mu \mathrm{g} / \mathrm{ml})$ of B12 for 6 hours and the second group (250 insects) was treated with $2 \mu \mathrm{g} / \mathrm{ml}$ of B12 for different periods of time (1, 2, 3, 4 hours). The results indicated that there was an almost identical trend between different times and B12 concentrations on the oxidative stress parameters examined, and the correlation factor between $\mathrm{O}_{2}$ and $\mathrm{H}_{2} \mathrm{O}_{2}$ showed a high positive correlation of 0.921 . These results confirmed that treating insects with vitamin B12 increases their ability to reduce oxidative stress factors and increase the ability of insects to use them in biological treatment of drug and plant residues.
\end{abstract}

Keywords: Vitamin B; Antioxidants; Oxidative stress; Physiophora alceae; Reactive oxygen species; Bioremediation.

\section{INTRODUCTION}

Drug and food production is considered as a huge industry worldwide, especially fruit and vegetables. Thus, more than $30 \%$ of fruit and vegetables are considered as loss as a result of pathogenic microbes or manufacturing processing (Pétriacq et al., 2018). These wastes lead to economic, social and even environmental impacts (Thassitou and Arvanitoyannis, 2001; Romanazzi et al., 2016; Pétriacq et al., 2018; Huang et al., 2020) as a result of greenhouse gases emissions. The environmental pollutants lead to destroy the ecosystem function and elevate the oxidative stress status in living organisms especially insects (Renault et al., 2016; Yousef et al., 2017; Nassar et al., 2020; Abdelfattah et al., 2021). In particular, the ecosystem functions focused on regulating ecological processes strengthens life systems and provides stability among trophic levels in the food chain and food web (Oliver et al., 2015; Delgado-Baquerizo et al., 2020). Therefore, the pollutants emission from food waste decaying can be released into the environment and biomagnified within 


\section{Eman A. Abdelfattah}

the food chain (Hop et al., 2002; Majed et al., 2016; Kumar et al., 2020). This results in increasing the threats on top invertebrates, predators and higher vertebrates (Lima, 1998). These pollutants have the ability to persist over long periods (e.g. persistent organic pollutants), and therefore, act as an essential threat factor to biodiversity (Vallack et al., 1998; Olisah et al., 2021). As, in a recent study, Abdelfattah et al. (2021) experimentally demonstrated the deleterious effect of normal levels of environmental pollutants on the oxidative stress parameters on different tissues of Physiophora alceae and Coccinella undecimpuctata adult insect, with respect to control levels. In Ailiopus thalasinus, the environmental pollutants emission from fertilizer production industry leads to elevate the levels of oxidative stress parameters which includes oxidants concentration and biomolecules damage levels which leads to oxidative stress (Abdelfattah et al., 2017; Yousef et al., 2019).To restore the oxidative stress hemostatic balance in insect, the activity of enzymatic and levels of non-enzymatic antioxidants should be elevated (Pisoschi and Pop, 2015; Abdelfattah et al., 2021).

Some studies have indicated that vitamin B12 is an antioxidant, and a lower status of vitamin B12 might be a potential trigger contributing to restore oxidative hemostasis, particularly in patients with diabetes (Al-Maskari et al., 2012; Solomon, 2015; Lee et al., 2016). Also, other studies promote that vitamin B12 acts as an antioxidant or anti-inflammation agent, which can reduce oxidative stress responses, which include inflammatory responses (Lee et al., 2016). Other studies demonstrate the mode of action of various antioxidants which includes induction of inflammation and cytokine as a result of oxidative stress induction (Voigt et al., 2013). These inflammation and antioxidant factors can facilitate tissue repair as a result of aggressors for a long time (Michaud et al., 2013). However, shorting the time in inflammation factors mechanism leads to several age-related diseases, including Alzheimer's and Parkinson's (Guarner and Rubio-Ruiz, 2015) and multiple modification of various living organisms' macromolecules (carbohydrates, proteins, lipids, and DNA) (Abdelfattah et al., 2017; Nassar et al., 2020). Also, it is assumed that the nuclear factor-erythroid-2-related factor (Nrf2) expression is a key regulator of antioxidant defenses (Kaspar et al., 2009; Sies et al., 2017).

Nowadays, many pharmaceuticals are listed as potential antioxidants by drug banks, including vitamins. These compounds are used to perform an essential role in restoring oxidative stress hemostasis, protect human health and behave as additives for cosmetics, food, and pharmaceutical products. Vitamin B12 is considered as a highly complex, essential vitamin, and it could be formed naturally by bacteria (Fang et al., 2017). Vitamin B12 as a drug was approved by U.S. Food and Drug Administration (FDA) and its mechanism of action depends in its role as a cofactor for several enzymes which include methionine synthase and L-methylmalonyl-CoA mutase enzymes (Wickramasinghe, 1995) that have an important role in synthesis of purines and pyrimidines bases of DNA and degradation of propionate compounds which is considered as an important reaction for proteins and fat metabolism. However, the deficiency of Vitamin B12 levels leads to accumulation of methylmalonyl CoA which is responsible for the neurological manifestations of B12 deficiency (Andrès et al., 2002).

In this context, oxidative stress is the significance of imbalanced quantities among the levels of oxidants such as superoxide anion radicals, hydrogen peroxide, hydroxyl radical or, and antioxidants such as Superoxide dismutase (SOD), catalase (CAT), glutathione peroxidase (GPx), carboxyl esterase hydroxylase $(\mathrm{CEH})$, glutathione reduced 


\section{Effect of different concentrations and application time of vitamin B12 on antioxidant response of Physiophora alceae}

(GSH), ascorbic acid, vitamin $\mathrm{E}$, vitamin $\mathrm{C}$ and vitamin B12 in the living organism. All known non-enzymatic and enzymatic antioxidants were used to reduce the deleterious effects of ROS on essential macromolecules which include DNA single strand breaks, protein carbonyls, lipid peroxides, enzyme inhibition, carbohydrate oxidation. Antioxidant responses especially non-enzymatic ones are considered as the fast and first defense line in the living organisms and all these antioxidants have been categorized from various arthropods exposed to variety of stressful abiotic and biotic factors (Lalouette et al., 2011; Lawniczak et al., 2013; Renault et al., 2016; Abdelfattah et al., 2017, 2021; Yousef et al., 2017).

Although the use of vitamin B12 after exposure to environmental pollutants from decaying food wastes is considered as an essential research point to determine the pattern of oxidative stress parameter response, yet, the effects of using vitamins especially vitamin B12 have been poorly examined in insects. House (1966) revealed that the growth rate and development in Agria affinis (Fallén) can be enhanced by vitamins $\mathrm{A}$ and $\mathrm{E}$ and concluded that fat-soluble vitamins can fix various defects in the larval nutritional diets contaminated with chemicals. Etebari and Matindoost (2005) concluded that multivitamins treatments as supplementary nutrients resulted in a significant increase in biological and economical parameters of silkworm, Bombyx mori, such as larval weight, female and male cocoon weight, pupal weight and egg productivity with respect to control insect, however it can reduce egg hatching in insect treated with multivitamins. Salem et al. (2014) demonstrated the beneficial gut microbes which supplement host, African cotton stainer's (Dysdercus fasciatus), with essential vitamins especially B vitamins and can be important to the host's metabolic homeostasis.
In this context, the present work aimed at assessing the physiological effects of the commercial vitamin B12 doses on adults Physiphora alceae which are often conveniently used as nectar feeder. The flower doesn't contain injected vitamins. So, using insects as an experimental insect to evaluate the oxidative stress parameters as a result of vitamin B12 administered was performed. These effects were investigated on the level of reactive oxygen species, enzymatic and non-enzymatic antioxidant mechanisms in gut tissues of the studied insects. Also, injection of adult $P$. alceae with the treatment dose $(2 \mu \mathrm{g} / \mathrm{ml})$ of vitamin B12 for different time intervals was investigated to show its effect on the levels of $\mathrm{O}_{2}{ }^{--}, \mathrm{H}_{2} \mathrm{O}_{2}$, SOD, and $\mathrm{GSH}$ from gut tissues of $P$. alceae adult.

\section{MATERIALS AND METHODS}

Insects rearing and vitamin $\mathrm{B} 12$
treatments

Adult insects of $P$. alceae were collected from Cairo University campus, identified and reared in the Entomology Department of the Faculty of Science, Cairo University (Giza, Egypt). Insects were reared in plastic boxes $(10 \times 10 \times 10$ $\mathrm{cm})$ at $37^{\circ} \mathrm{C}(\mathrm{RH} 69 \%, 12: 12 \mathrm{~h}$ Light: Dark), and they were supplied with nectar solution for feeding and decaying vegetables for egg laying and water. Before the adults were used for these experiments, they were starved for $24 \mathrm{~h}$ to eliminate the feeding effect. The commercial vitamin B12 with the name of ECAVIT B12 was obtained from the Health Insurance Authority, Egypt.

To study the effect of different concentrations of vitamin B12, a group of 250 adult insects of $P$. lalceae were obtained and divided into 5 subgroups, each contains 50 adult insects. The first subgroup was the control group and was not injected with vitamin B12 but received deionized water only $(1 \mu \mathrm{l})$. Insects of the other subgroups were injected with $1 \mu \mathrm{L}$ 


\section{Eman A. Abdelfattah}

of the prepared concentrations of vitamin B12 $(0.125,0.25,0.50$ and $1.0 \mu \mathrm{g} / \mathrm{ml}$, respectively). All injected Insects and the control group were dissected after $6 \mathrm{~h}$ to obtain their gut.

To study the effect of different post injection time, a group of 250 adult insects were used. They are divided into 5 subgroups each containing 50 adult insects. The first subgroup received deionized water only and acted as a control group, while the other subgroups were injected with a dose of $2 \mu \mathrm{g} / \mathrm{ml}$ of vitamin B12. The control and treated subgroups were dissected after $0,1,2,3$ and 4 hours of injections, respectively to obtain their gut.

Injection of each adult insect was carried out by using a micro syringe into the intersegmental membrane of $3^{\text {rd }}$ thoracic leg of insect under binocular with 10x magnification. The dissected gut was stored at $-20^{\circ} \mathrm{C}$ until use.

\section{Measurements of the amounts of superoxide anion radicals and hydrogen peroxide}

For each sample, The $\mathrm{O}_{2}{ }^{-}$ production rate of experimental samples was determined using a spectrophotometer according to the method of Chen and $\mathrm{Li}$ (2001). The reaction mixture contains 0.25 $\mathrm{ml}$ epinephrine $(1 \mathrm{mM}), 0.25 \mathrm{ml} \mathrm{NADPH}$ $(1 \mathrm{mM})$, and $0.5 \mathrm{ml}$ potassium phosphate buffer $(50 \mathrm{mM} ; \mathrm{pH}$ 7.0), and $150 \mu \mathrm{g}$ protein of experimental samples. The level of superoxide anion radical was determined by the rate of conversion of epinephrine to adrenochrome with $1 \mathrm{mM}$ $\mathrm{NADPH}$ as substrate. The absorbance difference $\left(\mathrm{A}_{485}-\mathrm{A}_{575}\right)$ was recorded. $\mathrm{O}_{2}{ }^{-}$ production rate was expressed as $\mathrm{OD} / \mathrm{mg}$ protein/min.

In addition, the $\mathrm{H}_{2} \mathrm{O}_{2}$ concentration was measured using spectrophotometer following the method described by Junglee et al. (2014) where $150 \mathrm{mg}$ of each body sample (or $150 \mu \mathrm{L}$ for hemolymph) was homogenized at $4{ }^{\circ} \mathrm{C}$ for $10 \mathrm{~min}$ into $1 \mathrm{ml}$ of a solution containing $0.25 \mathrm{ml}$ Trichloroacetic acid (TCA) (0.1\% (v:v)),
$0.5 \mathrm{ml} \mathrm{KI}(1 \mathrm{M})$ and $0.25 \mathrm{ml}$ potassium phosphate buffer (10 mM, pH 7.0). This procedure combines the extraction of $\mathrm{H}_{2} \mathrm{O}_{2}$ and the colorimetric reaction; samples were quickly covered with aluminum foil to limit their alteration by light. The blank was obtained by replacing KI by $0.5 \mathrm{ml}$ of $\mathrm{H} 2 \mathrm{O}$. The homogenates were then centrifuged at $12,000 \times \mathrm{g}$ for $15 \mathrm{~min}$ at 4 ${ }^{\circ} \mathrm{C}$. For each sample, an aliquot of $200 \mu 1$ of the supernatant was transferred to the well of an UV-microplate and incubated at $20{ }^{\circ} \mathrm{C}$ for $20 \mathrm{~min}$ before the absorbance was measured at $240 \mathrm{~nm}$. A calibration curve, obtained with $\mathrm{H}_{2} \mathrm{O}_{2}$ standard solutions prepared in $0.1 \%$ TCA, was used for quantification. $\mathrm{H}_{2} \mathrm{O}_{2}$ concentration was expressed as ppm. All samples and blanks were analyzed in triplicates.

\section{Measurements of the amounts of reduced glutathione}

The concentration of glutathione (GSH), which has a non-enzymatic antioxidant activity, was conducted by colorimetric methods according to the procedure of Allen et al. (1984). $200 \mathrm{mg}$ of each body sample $(200 \mu \mathrm{L}$ for hemolymph) was homogenized with $2 \mathrm{ml}$ of 5\% (w/v) TCA in $1 \mathrm{mM}$ EDTA before being centrifuged at $10,000 \times \mathrm{g}$ for $20 \mathrm{~min}$ at $4{ }^{\circ} \mathrm{C}$. A volume of $1 \mathrm{ml}$ of the reaction mixture, which contained $150 \mu$ of extract, $800 \mu \mathrm{l}$ of $0.1 \mathrm{M}$ phosphate buffer $(\mathrm{pH} 8.0)$, and $50 \mu \mathrm{l}(0.01 \%$ in $0.1 \mathrm{M}$ phosphate buffer, $\mathrm{pH}$ 8.0) of 5, $5^{\prime}$-Diothio bis-2-nitrobenzoic acid (DTNB), was mixed thoroughly, and then incubated at $25{ }^{\circ} \mathrm{C}$ for 20 minutes. The absorbance of the reaction mixture was measured at 412 $\mathrm{nm}$. The GSH content was determined from a GSH standard curve, and the GSH concentration was expressed in $\mu \mathrm{g} \mathrm{GSH} /$ mg protein.

\section{Measurements of the catalytic activities of superoxide dismutase enzyme}

For each replicate, SOD activity was measured based on the procedure described by Misra and Fridovich (1972). 


\section{Effect of different concentrations and application time of vitamin B12 on antioxidant response of Physiophora alceae}

The reaction mixture was as follows: 0.4 $\mathrm{ml}$ of a sodium carbonate buffer $(200 \mathrm{mM}$; $\mathrm{pH} 10.0), 35 \mu \mathrm{l}$ of EDTA (10 mM), $87 \mu \mathrm{l}$ of the supernatant of the appropriate tissue and $0.5 \mathrm{ml}$ of freshly prepared epinephrine $(15 \mathrm{mM})$. The absorbance was measured at $480 \mathrm{~nm}$. SOD activity was expressed as $\mathrm{OD} / \mu \mathrm{g} \mathrm{protein} / \mathrm{min}$.

\section{Total protein amount}

The total protein concentration was quantified for each body sample with Bradford's method (Bradford 1976), using Coomassie Brilliant Blue (COBB). A volume of $0.9 \mathrm{ml}$ of the dye reagent ( 10 mg COBB mixed with $5 \mathrm{~mL}$ methanol and $10 \mathrm{ml}$ of $85 \%$ O-phosphoric acid, completed to $100 \mathrm{~mL}$ with distilled water) was mixed with $0.1 \mathrm{ml}$ of body sample, then left for 2 min before measuring the optical density of the samples at $595 \mathrm{~nm}$. The blank consisted in distilled water instead of the protein sample. Bovine serum albumin (BSA) fraction V (SigmaAldrich) dissolved in $0.15 \mathrm{M} \mathrm{NaCl}$ was used as drawing the calibration curve.

\section{Statistical analysis}

As a first step, a robust test of equality of means was done for the equality of variance and test significantly effect of different experimental concentrations of vitamin B12 and time course post injection on physiological endpoints were measured $\left(\mathrm{O}_{2}{ }^{-{ }^{-}}, \mathrm{H}_{2} \mathrm{O}_{2}\right.$, SOD, and GSH) from gut tissues of $P$. alceae adult. In a second step, the effect of the different concentrations and time course post injection of vitamin $\mathrm{B} 12$ on the levels of $\mathrm{O}_{2}{ }^{-}, \mathrm{H}_{2} \mathrm{O}_{2}, \mathrm{SOD}$, and $\mathrm{GSH}$ in the gut of adult of $P$. alceae was assessed by performing a one-way analysis of variance (ANOVA), followed by Tukey's post-hoc tests when necessary. All statistical analyses were performed using IBM SPSS Statistics for Windows (Version 17.0. Armonk, NY: IBM Corp.).

\section{RESULTS AND DISCUSSION}

Robust tests of equality of means, revealed that, each case of the different concentrations and time course post injection of vitamin B12: (0, 0.125, 0.25, $0.5,1 \mu \mathrm{g} / \mathrm{mL})$ and $(0,1,2,3$, and $4 \mathrm{~h})$, had significance difference among each treatment of injected vitamin $\mathrm{B} 12$ on superoxide anion radical $\left(\mathrm{O}_{2}{ }^{\circ}\right)$, hydrogen peroxide $\left(\mathrm{H}_{2} \mathrm{O}_{2}\right)$, glutathione reduced (GSH) and superoxide dismutase antioxidant enzyme (SOD) measured in gut tissue homogenates of Physiphora alceae (Table 1).

Table 1. Robust tests of equality of means, showed, the Welch, Brown Forsythe, degree of freedom and significance values of superoxide anion radical $\left(\mathrm{O}_{2}{ }^{-}\right)$, hydrogen peroxide $\left(\mathrm{H}_{2} \mathrm{O}_{2}\right)$, glutathione reduced $(\mathrm{GSH})$ and superoxide dismutase antioxidant enzyme (SOD) measured in gut tissue homogenates of adults of Physiphora alceae. Adult insects were injected with different concentrations of vitamin B12: $(0,0.125,0.25,0.5,1 \mu \mathrm{g} / \mathrm{mL})$ and injected with $2 \mu \mathrm{g} / \mathrm{m}$ for different time course post injection $(0,1,2,3$, and $4 \mathrm{~h})$.

\begin{tabular}{|c|c|c|c|c|c|c|}
\hline Item & Test & Factor & Welch & Brown Forsythe & $d f$ & P-value \\
\hline \multirow{4}{*}{ ROS } & \multirow{2}{*}{$\mathbf{H}_{2} \mathbf{O}_{2}$} & Conc. & 170.2 & 117.9 & 4 & $<0.0001$ \\
\hline & & Time & 3.4 & 3.7 & 4 & $<0.0001$ \\
\hline & \multirow{2}{*}{$\mathbf{O}_{2}{ }^{-{ }^{-}}$} & Conc. & 30.5 & 38.4 & 4 & $<0.0001$ \\
\hline & & Time & 45.1 & 85.5 & 4 & $<0.0001$ \\
\hline \multirow[t]{4}{*}{ AO } & \multirow{2}{*}{ SOD } & Conc. & 192.8 & 87.8 & 4 & $<0.0001$ \\
\hline & & Time & 133.9 & 92.9 & 4 & $<0.0001$ \\
\hline & \multirow{2}{*}{ GSH } & Conc. & 1131.3 & 1096 & 4 & $<0.0001$ \\
\hline & & Time & 18.3 & 26.2 & 4 & $<0.0001$ \\
\hline
\end{tabular}




\section{Eman A. Abdelfattah}

Oxidative stress occurred as a result of over production of oxidants, including $\mathrm{O}_{2}{ }^{--}$and $\mathrm{H}_{2} \mathrm{O}_{2}$ and depletion of both non-enzymatic and enzymatic antioxidants, including GSH and SOD. There are a lot of external and internal antioxidant factors related to decrease the concentration of oxidants and increase the concentration of antioxidants, for example, Van De Lagemaat et al. (2019) reported that antioxidant properties of vitamin B12 includes the depletion in the concentration of $\mathrm{O}_{2}{ }^{--}$, amounts of protein carbonyls and lipid peroxides, however, the antioxidant ability of vitamin B12 can increase the concentration of GSH. The present results revealed that vitamin $\mathrm{B} 12$ treatment at the concentration of $2 \mu \mathrm{g} / \mathrm{ml}$ doesn't affect the concentration of $\mathrm{H}_{2} \mathrm{O}_{2}$ at 2 hours post injection treatment in the adult of $P$. alceae. However, the concentration of $\mathrm{H}_{2} \mathrm{O}_{2}$ decreased, with respect to control, at concentration range 0.125 to $1 \mu \mathrm{g} / \mathrm{mL}$ (Figs. 1 and 2).

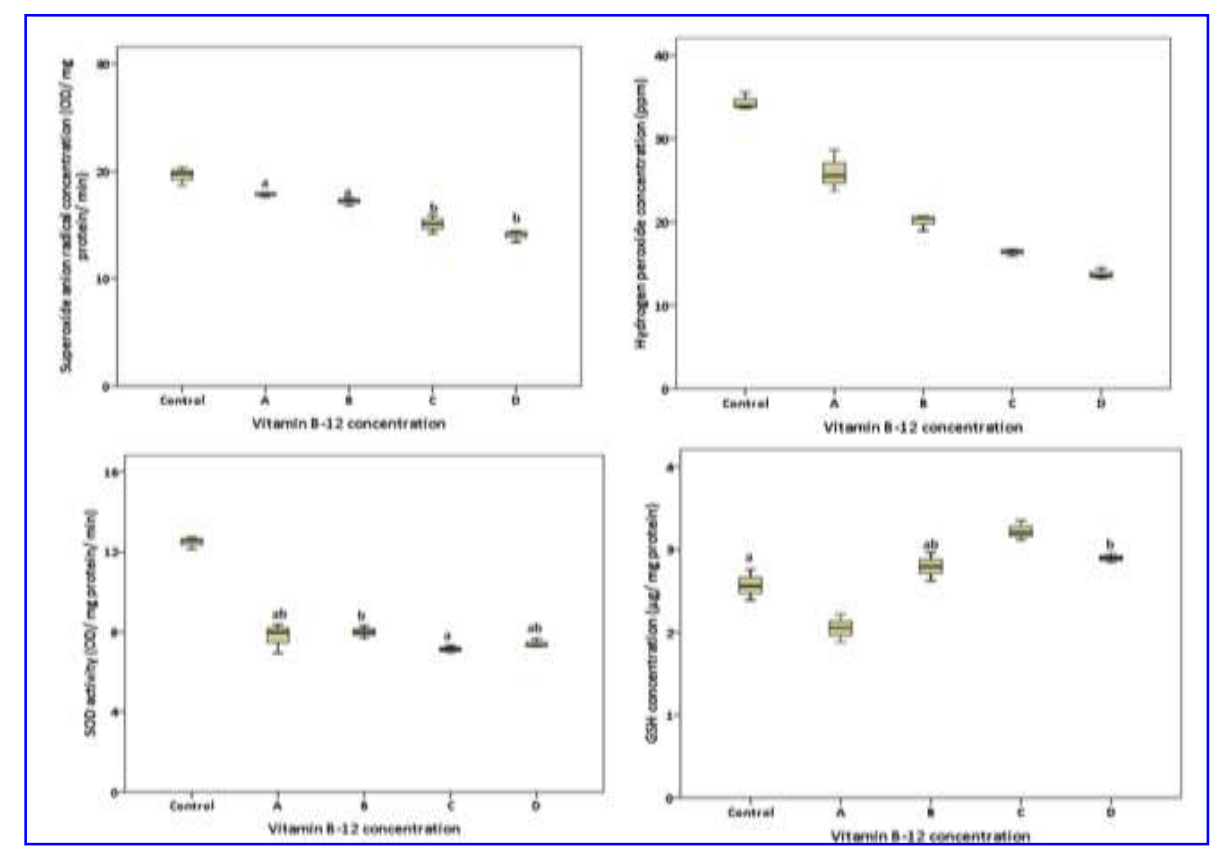

Fig. 1. Effects of different concentration of commercial vitamin $\mathrm{B} 12$ on the amount (mean, $\mathrm{P} 25$, P75) of superoxide anion radical $\left(\mathrm{O}_{2}{ }^{-}\right)$, hydrogen peroxide $\left(\mathrm{H}_{2} \mathrm{O}_{2}\right)$, superoxide dismutase antioxidant enzyme (SOD) and glutathione reduced (GSH) measured in gut tissue homogenates of adults of Physiphora alceae. Adult insects were injected with different doses of vitamin B12: $0,0.125,0.25,0.5$, and $1 \mu \mathrm{g} / \mathrm{mL}$. 'Small letters' at the top of the boxplot report the statistical comparisons among control and vitamin B12-treated larvae at each tissue separately (ANOVA, Tukey's-b test, $p<0.05$ ). 


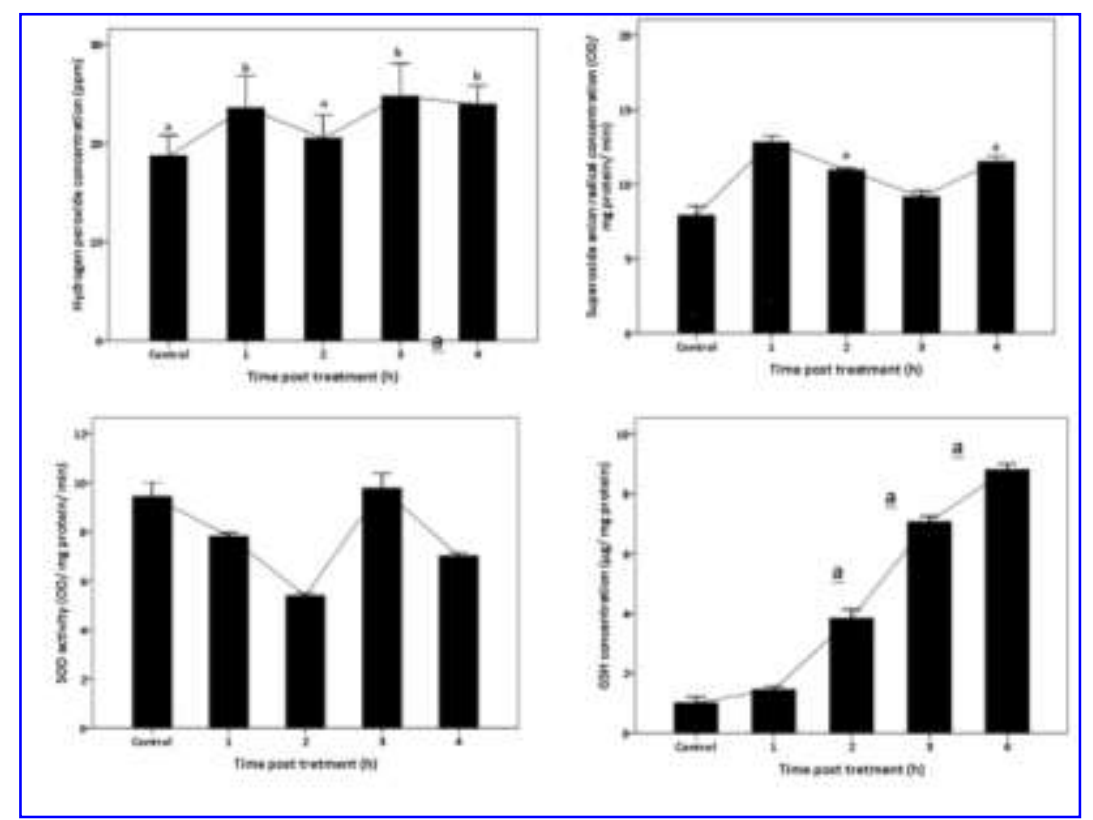

Fig. 2. Effects of different concentration of commercial vitamin $\mathrm{B} 12$ on the amount (mean, P25, P75) of superoxide anion radical $\left(\mathrm{O}_{2}{ }^{\circ}\right)$, hydrogen peroxide $\left(\mathrm{H}_{2} \mathrm{O}_{2}\right)$, glutathione reduced $(\mathrm{GSH})$ and superoxide dismutase antioxidant enzyme (SOD) measured in gut tissue homogenates of adults of Physiphora alceae. Adult insects were injected with different time course post injection of vitamin B12: $0,1,2,3$, and $4 \mathrm{~h}$. 'Small letters' at the top of the boxplot report the statistical comparisons among control and vitamin B12-treated larvae at each tissue separately (ANOVA, Tukey's-b test, $p<$ $0.05)$.

The highest concentration of vitamin B12 application $(1 \mu \mathrm{g} / \mathrm{ml})$ resulted in a high depletion in the levels of $\mathrm{O}_{2}{ }^{-}$and $\mathrm{H}_{2} \mathrm{O}_{2}$, with the factor of 0.25 -x and $0.67-\mathrm{x}$ respectively with respect to control value $(\mathrm{SS}=59.1,818.8 ; \mathrm{df}=4,4 ; \mathrm{MS}=14.7$, 204.7; $p<0.001$ ) (Fig. 1). The low $\mathrm{H}_{2} \mathrm{O}_{2}$ levels were significantly lower in the gut homogenates of adult insect injected with $1 \mu \mathrm{L}$ of vitamin B12 at the concentrations $(0.125,0.25,0.5$, and $1 \mu \mathrm{g} / \mathrm{ml})$ as compared with the control. This result recommends the reality of a threshold concentration of vitamin B12 administration to avoid production of oxidants. Also, the results demonstrated a strong positive correlation between vitamin $\mathrm{B} 12$ and concentration of $\mathrm{GSH}$ with a polynomial type of equation and the accuracy was checked by the value of chi square (Table 2). However, there was a negative correlation among vitamin $\mathrm{B} 12$ and levels of $\mathrm{O}_{2}{ }^{-}$or $\mathrm{H}_{2} \mathrm{O}_{2}$ or SOD.

Table 2. Pearson's correlation coefficient between vitamin concentration and: superoxide anion radical $\left(\mathrm{O}_{2}{ }^{\circ}\right)$, hydrogen peroxide $\left(\mathrm{H}_{2} \mathrm{O}_{2}\right)$, glutathione reduced $(\mathrm{GSH})$ and superoxide dismutase antioxidant enzyme (SOD) measured in gut tissue homogenates of adults of Physiphora alceae.

\begin{tabular}{|c|c|c|c|c|c|}
\hline Item & Test & $\mathbf{r}$ & Equation & Type of equation & $\mathbf{R}^{2}$ \\
\hline \multirow{2}{*}{ ROS } & $\mathrm{H}_{2} \mathrm{O}_{2}$ & $-0.964 * *$ & $Y=-38.1 x+1271.7$ & \multirow{2}{*}{ Linear } & 0.96 \\
\hline & $\mathbf{O}_{2}^{*^{-}}$ & $-0.960 * *$ & $Y=-185 x+3135$ & & 0.94 \\
\hline \multirow{3}{*}{ AO } & SOD & $-0.758 * *$ & $Y=-132 x+1544$ & \multirow{3}{*}{ Polynomial } & \multirow{2}{*}{0.72} \\
\hline & GSH & $0.633^{*}$ & $Y=1257 x^{2}-58850 x+6744$ & & \\
\hline & & & & & 0.52 \\
\hline
\end{tabular}




\section{Eman A. Abdelfattah}

There are a few literature reviews focused on the effects of vitamin B12 administration on insect's biochemistry and physiology, so, the interpreting of this research results is done with respect to animal taxa and even humans. In vitro analysis of human aortic endothelial cells which were supplied with Vitamin B12 in the form of cyanocobalamin, showed a depletion of superoxide levels in mitochondria and cytosol (Moreira et al,. 2011). Chan et al. (2018) reported a depletion rate of superoxide in the longevans rats in case of in vivo administration of vitamin B12. This depletion may be related to scavenging activity of vitamin B12 using enzymatic processes (Moreira et al., 2011; Chan et al., 2018; Van De Lagemaat et al., 2019).

The link between increased levels of glutathione and vitamin B12 administration was reported to be indirect by Manzanares and Hardy (2010) and Karamshetty et al. (2016). These finding is matched with the finding of the present research which includes a significant elevation of GSH at the B12 concentration 0.5 and $1 \mu \mathrm{g} / \mathrm{mL}$ and all-time course post injection of vitamin B12 (1-4 h) of the gut homogenates of adult $P$. alceae (Figs. 1 and 2). In this context, Van De Lagemaat et al. (2019) concluded that there was an obvious relation between vitamin B12 and oxidative stress. This direct or indirect relationship approved that lower B12 status is associated with the elevation of pro-oxidants and depletion of antioxidants.

Birch et al. (2009) and Politis et al. (2010) revealed that vitamin B12 may protect against oxidative stress especially in inflammation cases by controlling cytokines and growth factors expression especially in rates and examined patients. This hypothesis can be achieved through adjusting the activity of transcription factor- $\kappa \mathrm{B}$. The depletion in vitamin B12 led to increasing the levels of oxidants and decreasing the levels of antioxidants especially GSH as shown in Figure (1).
This may be clarified through the following mechanism, depletion of vitamin B12 leads to decrease the level of homocysteine which is considered as a cofactor of B12. This depletion rate leads to decrease the conversion rate of methionine and elevate homocysteine levels which leads to increased levels of oxidants as a result of self auto-oxidation and formation of $\mathrm{H}_{2} \mathrm{O}_{2}$ (Loscalzo 1996; Tyagi, 2005).

There was a significant decrease of levels of SOD, antioxidant enzyme activity, in the gut homogenates of the investigated adult insect $P$. alceae as a result of increasing the concentration and time of post injection of vitamin B12 into insect as compared with control (Fig. 1), except in the gut tissues of 3 hours post injection dose. SOD is well known for its ability to scavenge $\mathrm{O}_{2}{ }^{-}$(Ighodaro and Akinloye, 2018; Yousef et al., 2017; Abdelfattah et al., 2021). Ighodaro and Akinloye (2018) classified the antioxidants response against $\mathrm{O}_{2}{ }^{-}$into $1^{\text {st }}, 2^{\text {nd }}, 3^{\text {rd }}$ and $4^{\text {th }}$ line antioxidants defense. The first line of antioxidants action includes SOD, CAT and GPX even in case of endogenous or exogenous source generation of $\mathrm{O}_{2}{ }^{-}$The slight increase activity of SOD recorded in the present study may propose that the enzyme has ability to control the oxidant production in treated insect, with the aid of vitamin B12 action, so it may give the ability to protect from induction of oxidative action , depending on physiological situation (Álvarez-Diduk and Galano, 2015; Yousef et al., 2019; Abdelfattah et al., 2021).

The time series modelling of average concentrations of the injected vitamin B12 doses was shown in Figure (3). The results reported that there was a prediction increase in the level of oxidative stress parameters when the dose of vitamin B12 increases. To determine a proper model for a given time series data, it is necessary to carry out the autocorrelation factor (ACF) and partial 


\section{Effect of different concentrations and application time of vitamin B12 on antioxidant response of Physiophora alceae}

autocorrelation factor (PACF) analysis. Figure (4) showed that there were significantly large sample ACF values at increasing lags, which do not diminish quickly. The diagnosis and testing a supposed model through analysing residual series between forecasted series and original series, it can be concluded that the residual series were appeared as a white noise series as ACF, and ACF in Figure (4) are nearly equal to zero. This implies that the supposed ARIMA model is valid for data in Figure (3). Therefore, temporal analysis of vitamin B12 dose revealed significant effect of time on oxidative stress parameters, so, using spatial analysis of pollutants concentration a long pollution gradient was feasible.

In this study, the effects of time course and concentration course of vitamin
B12 were examined. Vitamin B12 may be used as exo-non enzymatic antioxidants to scavenge the oxidants, this compound is a vital micronutrient essential for metabolism and catabolism (Moreira et al., 2011). When used vitamin B12 as antioxidants of oxidative stress generated from exposure of environmental pollutants resulting from decaying vegetables, the adults of the fly $P$. alceae which received highest concentration of vitamin $\mathrm{B} 12$ were characterized by low levels of $\mathrm{H}_{2} \mathrm{O}_{2}$. Also, the experimental insects left for the highest time post injection of vitamin B12, were characterized by increasing their concentration of GSH. This finding suggests the ability of $\mathrm{B} 12$ to protect $P$. alceae against oxidative stress resulting from environmental pollution and this will help this insect to be used as a bioremediation tool of drug and vegetable wastes.

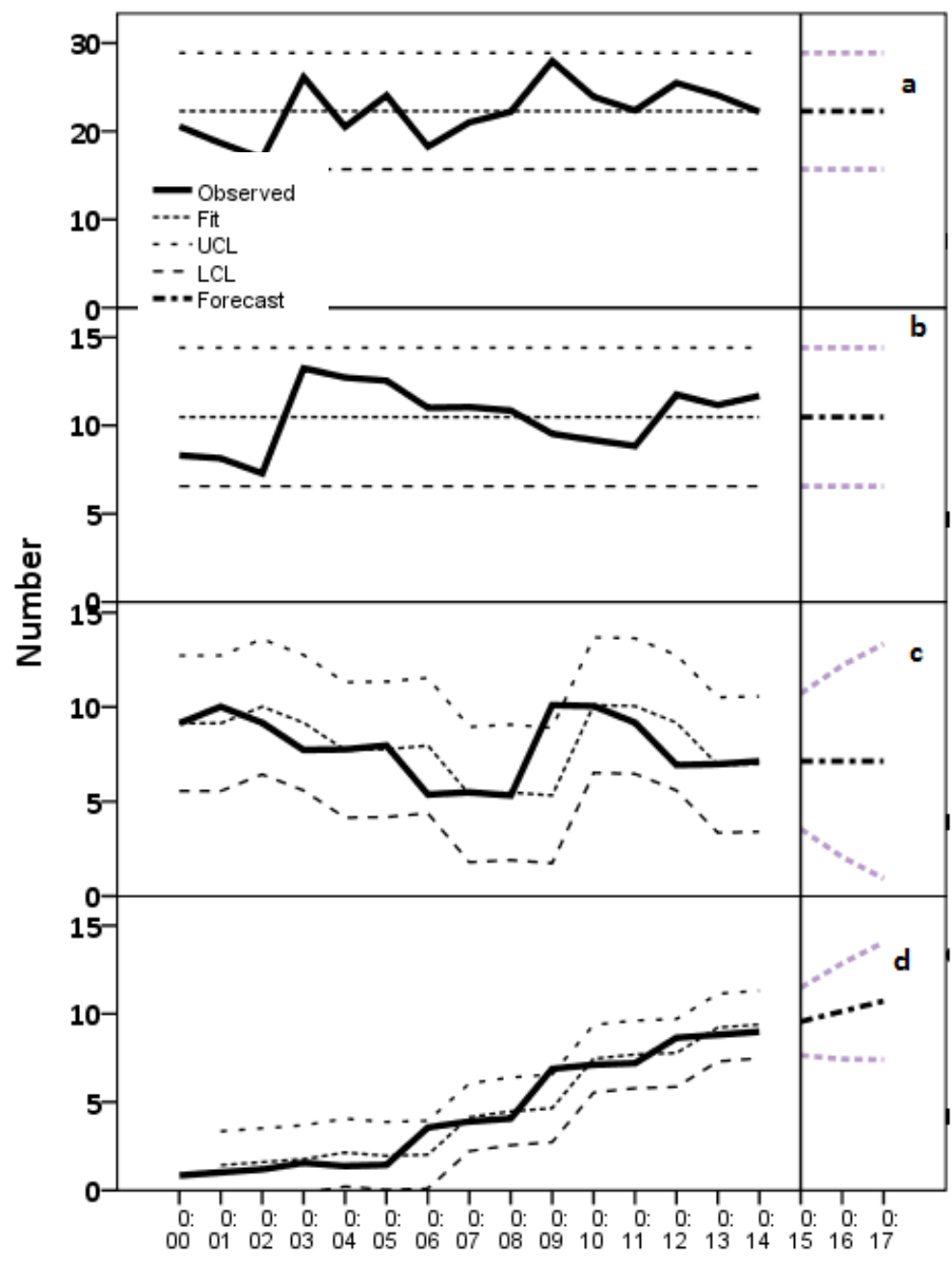

Fig. 3. Time series of observed, fit, upper limit, lower limit, and forecast of time course post injection of vitamin $\mathrm{B} 12(0,1,2$, 3 , and $4 \mathrm{~h}$ ) on the tested oxidative stress parameters (a) superoxide anion radical $\left(\mathrm{O}_{2}{ }^{\circ-}\right)$, (b) hydrogen peroxide $\left(\mathrm{H}_{2} \mathrm{O}_{2}\right)$, (c) glutathione reduced (GSH) and (d) superoxide dismutase antioxidant enzyme (SOD) measured in gut tissue homogenates of adult of Physiphora alceae. 
Eman A. Abdelfattah

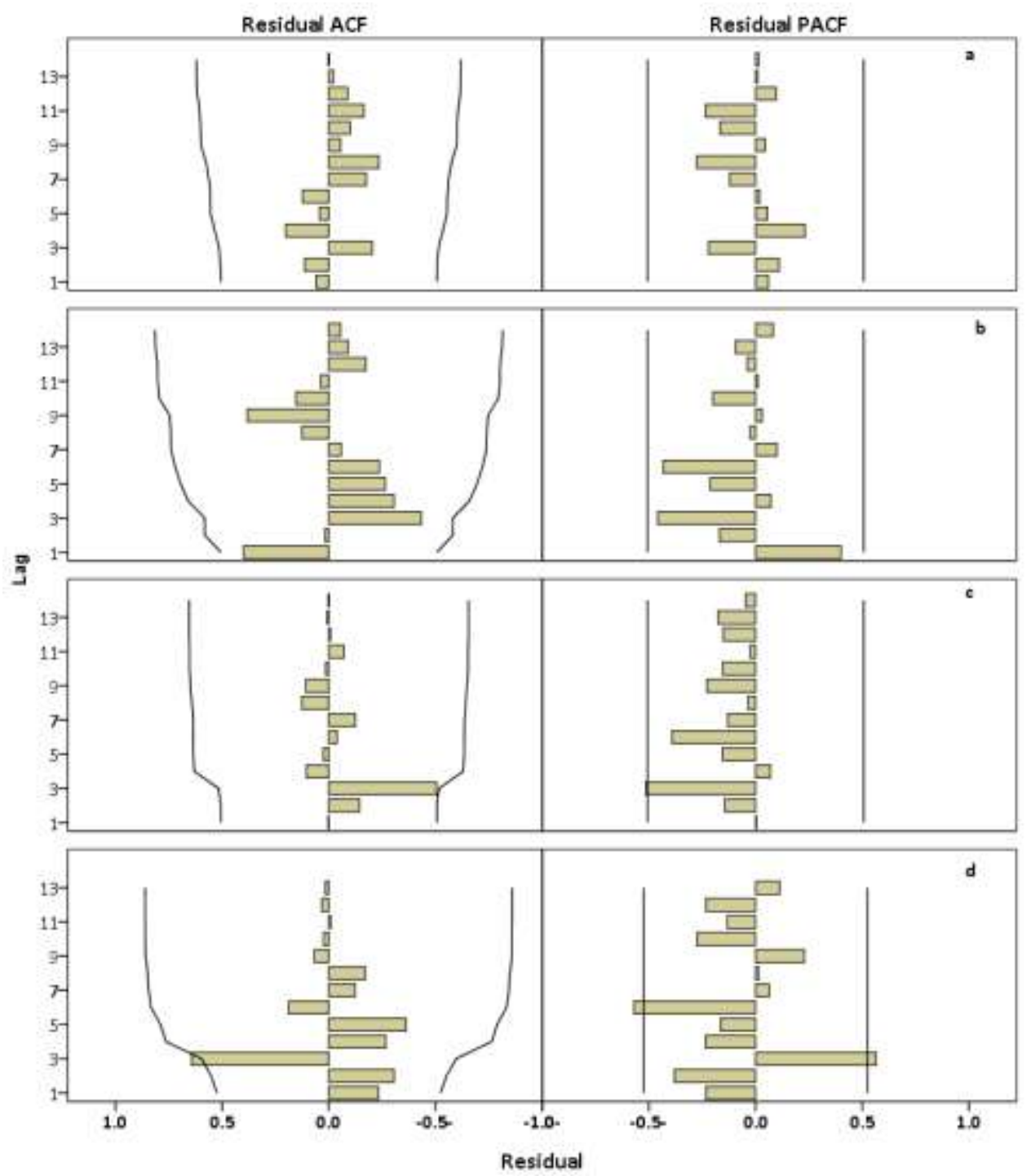

Fig. 4. The autocorrelation function (ACF), and partial autocorrelation function plot (PACF) of the residual series between the forecasted series and the real (differential) series of time course post injection of vitamin $\mathrm{B} 12(0,1,2,3$, and $4 \mathrm{~h})$ on the tested oxidative stress parameters (a) superoxide anion radical $\left(\mathrm{O}_{2}{ }^{\circ}\right)$, (b) hydrogen peroxide $\left(\mathrm{H}_{2} \mathrm{O}_{2}\right)$, (c) glutathione reduced $(\mathrm{GSH})$ and $(\mathrm{d})$ superoxide dismutase antioxidant enzyme (SOD) measured in gut tissue homogenates of adult of Physiphora alceae. Solid lines represent the upper and lower confidence limit coefficient.

\section{Acknowledgments}

Many thanks for grateful to Prof. Magdi Shaaban Ali El-Hawagry, Professor of Taxonomy at Entomology Department, Faculty of Science, Cairo University, Egypt for his help in identifying insect. This study was done at the Entomology Department, Faculty of Science, Cairo University, Egypt.

\section{REFERENCES}

Abdelfattah, E.A. (2016). Biomolecules oxidation and antioxidant enzymes response as a result of injection of oxidative stressor into 5th instar of Schistocerca gregaria (Orthoptera, Acrididae). Entomol. Ornithol. Herpetol., 5(181): 2161-0983. 


\section{Effect of different concentrations and application time of vitamin B12 on antioxidant response of Physiophora alceae}

Abdelfattah, E.A.; Augustyniak, M. and Yousef, H.A. (2017). Biomonitoring of genotoxicity of industrial fertilizer pollutants in Aiolopus thalassinus (Orthoptera: Acrididae) using alkaline comet assay. Chemosphere, 182: 762-770.

Abdelfattah, E.A.; Augustyniak, M. and Yousef, H.A. (2021). Stage-, sexand tissue-related changes in $\mathrm{H} 2 \mathrm{O} 2$, glutathione concentration, and glutathione-dependent enzymes activity in Aiolopus thalassinus (Orthoptera: Acrididae) from heavy metal polluted areas. Ecotoxicology, 30(3): 478491.

Allen, R.G.; Farmer, K.J.; Newton, R.K. and Sohal, R.S. (1984). Effects of paraquat administration on longevity, oxygen consumption, lipid peroxidation, superoxide dismutase, catalase, glutathione reductase, inorganic peroxides and glutathione in the adult housefly. Compar. Biochem. and Physi. (C): Compa. Pharma., 78(2): 283-288.

Al-Maskari, M.Y.; Waly, M.I.; Ali, A.; AlShuaibi, Y.S. and Ouhtit, A. (2012). Folate and vitamin B12 deficiency and hyperhomocysteinemia promote oxidative stress in adult type 2 diabetes. Nutrition, 28(7-8): e23e. 26

Álvarez-Diduk, R. and Galano, A. (2015). Adrenaline and noradrenaline: protectors against oxidative stress or molecular targets? J. Phys. Chem., B 3491-119:3479

Ames, B.N. (2006). Low micronutrient intake may accelerate the degenerative diseases of aging through allocation of scarce micronutrients by triage. Proc. Nat. Acad. Sci., 103(47): 17589-17594.

Ames, B.N. (2010). Prevention of mutation, cancer, and other age- associated diseases by optimizing micronutrient intake. J. Nucleic Acids, 2010:1-11.

Andrès, E.; Noel, E. and Goichot, B. (2002). Metformin-associated vitamin B12 deficiency. Archives Internal Medicine-2251:(19)162, .2252

Birch, C.S.; Brasch, N. E.; McCaddon, A. and Williams, J. H. (2009). A novel role for vitamin B12: cobalamins are intracellular antioxidants in vitro. Free Radical Biol. Medicine, 47(2): 184-188.

Bradford, M. M. (1976). A rapid and sensitive method for the quantitation of microgram quantities of protein utilizing the principle of protein-dye binding. Anal. Biochem. 72(1): 248-254.

Chan, W.; Almasieh, M.; Catrinescu, M.M. and Levin, L.A. (2018). Cobalamin-associated superoxide scavenging in neuronal cells is a potential mechanism for vitamin B12-deprivation optic neuropathy. Am. J. Pathol.,172-160:(1)188 .

Chen, W.P. and Li, P.H. (2001). Chilling induced $\mathrm{Ca} 2+$ overload enhances production of active oxygen species in maize (Zea mays L.) cultured cells: the effect of abscisic acid treatment. Plant, Cell Environ.800-791:(8)24, .

Delgado-Baquerizo, M.; Reich, P.B.; Trivedi, C.; Eldridge, D. J.; Abades, S.; Alfaro, F. D., ... and Singh, B.K. (2020). Multiple elements of soil biodiversity drive ecosystem functions across biomes. Nature Ecol. Evol., 4(2):220-210

Etebari, K. and Matindoost, L. (2005). Application of multi-vitamins as supplementary nutrients on biological and economical characteristics of silkworm Bombyx mori L. J. Asia-Pacific Entomol., 8(1):112-107 


\section{Eman A. Abdelfattah}

Fang, H.; Kang, J. and Zhang, D. (2017). Microbial production of vitamin B 12: a review and future perspectives. Microbial cell factories, 16(1):14-1

Frijhoff, J.; Winyard, P.G.; Zarkovic, N.; Davies, S.S.; Stocker, R.; Cheng, D.and Ghezzi, P. (2015). Clinical relevance of biomarkers of oxidative stress. Antioxidants Redox Signaling, 23(14): 11441170.

Green, R.; Allen, L.H.; Bjørke-Monsen, A.L.; Brito, A.; Guéant, J.L.; Miller, J.W., ... and Yajnik, C. (2017). Vitamin B 12 deficiency. Nature reviews Disease primers, 3(1): 1-20.

Guarner, V. and Rubio-Ruiz, M.E. (2015). Low-grade systemic inflammation connects aging, metabolic syndrome and cardiovascular disease. Aging and health-A systems Biology Perspective, 40: 99-106.

Hop, H.; Borgå, K.; Gabrielsen, G.W.; Kleivane, L. and Skaare, J.U. (2002). Food web magnification of persistent organic pollutants in poikilotherms and homeotherms from the Barents Sea. Environ. Sci. Technol., 36(12): 2597-2589 .

House, H.L. (1966). Effects of vitamins E and $\mathrm{A}$ on growth and development, and the necessity of vitamin $\mathrm{E}$ for reproduction in the parasitoid Agria affinis (Fallen) (Diptera, Sarcophagidae). J. Insect Physiol., 12(4):417-409

Huang, S.; Wang, T.; Chen, K.; Mei, M.; Liu, J. and Li, J. (2020). Engineered biochar derived from food waste digestate for activation of peroxymonosulfate to remove organic pollutants. Waste Management, 107:211-218.

Ighodaro, O.M. and Akinloye, O.A. (2018). First line defence antioxidants-superoxide dismutase (SOD), catalase (CAT) and glutathione peroxidase (GPX): Their fundamental role in the entire antioxidant defence grid. Alex. J. Med., 54(4):293-287

Junglee, S.; Urban, L.; Sallanon, H. and Lopez-Lauri, F. (2014). Optimized assay for hydrogen peroxide determination in plant tissue using potassium iodide. Am. J. Analy. Chem., 5: 730-736.

Karamshetty, V.; Acharya, J.D.; Ghaskadbi, S. and Goel, P. (2016). Mathematical modeling of glutathione status in type 2 diabetics with vitamin B12 deficiency. Frontiers in cell Develop. Biol., 4: 16.

Kaspar, J.W.; Niture, S.K. and Jaiswal, A.K. (2009). Nrf2: INrf2 (Keap1) signaling in oxidative stress. Free Radical Biology and Medicine, 47(9): 1304-1309.

Kim, M.A.; Cho, H.J.; Bae, S.H.; Lee, B.; Oh, S.K.; Kwon, T.J., ... and Lee, K.Y. (2016). Methionine sulfoxide reductase B3-targeted in utero gene therapy rescues hearing function in a mouse model of congenital sensorineural hearing loss. Antioxidants Redox Signaling, 24(11): 590-602.

Kumar, A.; M.M.S.; Chaturvedi, A.K.; Shabnam, A.A.; Subrahmanyam, G.; Mondal, R., ... and Yadav, K.K. (2020). Lead toxicity: health hazards, influence on food chain, and sustainable remediation approaches. Int. J.Environ. Res. Public Health, 17(7):2179

Lalouette, L.; Williams, C.M.; Hervant, F.; Sinclair, B.J. and Renault, D. (2011). Metabolic rate and oxidative stress in insects exposed to low temperature thermal fluctuations. Comp. Biochem. Physiol., A, 158:229-234

Lawniczak, M.; Romestaing, C.; Roussel, D.; Maazouzi, C.; Renault, D. and Hervant, F. (2013). Preventive antioxidant responses to extreme 


\section{Effect of different concentrations and application time of vitamin B12 on antioxidant response of Physiophora alceae}

oxygen level fluctuation in a subterranean crustacean. Comp. Biochem. Physiol., A, 165:299303.

Lee, Y. J.; Wang, M.Y.; Lin, M.C. and Lin, P.T. (2016). Associations between vitamin B-12 status and oxidative stress and inflammation in diabetic vegetarians and omnivores. Nutrients, 8(3): 118.

Liguori, I.; Russo, G.; Curcio, F.; Bulli, G.; Aran, L.; Della-Morte, D., ... and Abete, P. (2018). Oxidative stress, aging, and diseases. Clin. Interventions Aging, 13: 757.

Lima, S. L. (1998). Nonlethal effects in the ecology of predator-prey interactions. Bioscience, 48(1):25 34.

Loscalzo, J. (1996). The oxidant stress of hyperhomocyst (e) inemia. J. Clin. Investigation, 98(1): 5-7.

Majed, N.; Real, M.; Isreq, H.; Akter, M. and Azam, H.M. (2016). Food adulteration and bio-magnification of environmental contaminants: a comprehensive risk framework for Bangladesh. Frontiers in Environmental Science.34:4,

Manzanares, W. and Hardy, G. (2010). Vitamin B12: the forgotten micronutrient for critical care. Current Opinion Clin. Nutr. Metabolic Care.668-662:(6)13,

Michaud, M.; Balardy, L.; Moulis, G.; Gaudin, C.; Peyrot, C.; Vellas, B., ... and Nourhashemi, F. (2013). Proinflammatory cytokines, aging, and age-related diseases. J. Am. Medical Directors Assoc., 14(12): 877-882.

Misra, H.P. and Fridovich, I. (1972). The role of superoxide anion in the autoxidation of epinephrine and a simple assay for superoxide dismutase. J. Biol. Chem., 247(10): 3170-3175.

Moreira, E.S.; Brasch, N.E. and Yun, J. (2011). Vitamin B12 protects against superoxide-induced cell injury in human aortic endothelial cells. Free Radical Biology and Medicine, 51(4): 876-883.

Nassar, M.I.; Abd El-Monem, D.H.; Youssef, M.; Ibrahim, S.M.; Mohamed, S.M.; Abd-Aldayem, M.S., \& abdelfattah, E.A. (2020). Bee venom drug potentiality on the macromolecules damage of the larval gut of Hermetia illucens (1.), (Diptera: Stratiomyidae). J. Egypt. Soc. Parasitol., 50(3): 488-493.

Noori, S. (2012). An overview of oxidative stress and antioxidant defensive system. Open access scientific reports, 1(8): 1-9.

Nowotny, K.; Jung, T.; Höhn, A.; Weber, D. and Grune, T. (2015). Advanced glycation end products and oxidative stress in type 2 diabetes mellitus. Biomolecules, 5(1): 194222.

O'Leary, F. and Samman, S. (2010). Vitamin B12 in health and disease. Nutrients.316-299:(3)2,

Olisah, C.; Adams, J.B. and Rubidge, G. (2021). The state of persistent organic pollutants in South African estuaries: A review of environmental exposure and sources. Ecotoxicol. Environ. Safety, 219 :112-316.

Oliver, T.H.; Heard, M.S.; Isaac, N.J.; Roy, D.B.; Procter, D.; Eigenbrod, F.; ... and Bullock, J. M. (2015). Biodiversity and resilience of ecosystem functions. Trends in Ecology and Evolution., 30(11): 684-673

Pétriacq, P.; López, A. and Luna, E. (2018). Fruit decay to diseases: can induced resistance and priming help?. Plants, 7(4):77.

Phaniendra, A.; Jestadi, D.B. and Periyasamy, L. (2015). Free radicals: properties, sources, targets, and their implication in 


\section{Eman A. Abdelfattah}

various diseases. Ind. J. Clin. Biochem., 30(1):11-26.

Pisoschi, A.M. and Pop, A. (2015). The role of antioxidants in the chemistry of oxidative stress: A review. Eur. J. Medic. Chem., 97: 55-74.

Politis, A.; Olgiati, P.; Malitas, P.; Albani, D.; Signorini, A.; Polito, L.; ... and Serretti, A. (2010). Vitamin B12 levels in Alzheimer's disease: association with clinical features and cytokine production. J. Alzheimer's Disease, 19(2): 481488.

Renault, D.; Dorrah, M.A.; Mohamed, A.A.; Abdelfattah, E.A. and Bassal, T.T. (2016). Assessment of oxidative stress and activities of antioxidant enzymes depicts the negative systemic effect of ironcontaining fertilizers and plant phenolic compounds in the desert locust. Environ. Sci. Pollut. Res., 23(21): 21989-22000.

Romanazzi, G.; Sanzani, S.M.; Bi, Y.; Tian, S.; Martínez, P. G. and Alkan, N. (2016). Induced resistance to control postharvest decay of fruit and vegetables. Postharvest Biol. Technol., 122:82-94.

Salem, H.; Bauer, E.; Strauss, A.S.; Vogel, H.; Marz, M. and Kaltenpoth, M. (2014). Vitamin supplementation by gut symbionts ensures metabolic homeostasis in an insect host. Proceedings of the Royal Society B: Biological Sciences, 281:1796-1838 .

Sies, H., Berndt, C., \& Jones, D. P. (2017). Oxidative stress. Annu. Rev. Biochem. 86, 715-748.

Solomon, L.R. (2015). Functional cobalamin (vitamin B12) deficiency: role of advanced age and disorders associated with increased oxidative stress. Eur. J. Clin. Nutr.,69(6):687-692.
Thassitou, P.K. and Arvanitoyannis, I.S. (2001). Bioremediation: a novel approach to food waste management. Trends in Food Sci. Technol.,12(5-6):185-196.

Tyagi, N.; Sedoris, K.C.; Steed, M.; Ovechkin, A.V.; Moshal, K.S. and Tyagi, S.C. (2005). Mechanisms of homocysteine-induced oxidative stress. Am. J. Physiol.-Heart and Circulatory Physiol., 289(6): H2649-H2656.

Vallack, H.W.; Bakker, D.J.; Brandt, I.; Broström-Lundén, E.; Brouwer, A.; Bull, K. R., ... and Taalman, R.D. (1998). Controlling persistent organic pollutants-what next? Environ. Toxicol. Pharmacol., 6(3):143-175.

Van De Lagemaat, E.E.; de Groot, L.C. and Van Den Heuvel, E.G. (2019). Vitamin B12 in relation to oxidative stress: a systematic review. Nutrients, 11(2): 482.

Voigt, A.; Rahnefeld, A.; Kloetzel, P.M.P. and Krüger, E. (2013). Cytokineinduced oxidative stress in cardiac inflammation and heart failureHow the ubiquitin proteasome system targets this vicious cycle. Frontiers in Physiology, 4: 42.

Wickramasinghe, S.N. (1995). 1Morphology, biology and biochemistry of cobalamin-and folate-deficient bone marrow cells. Bailliere's clinical haematology,8(3): 441-459.

Yousef, H.A.; Abdelfattah, E.A. and Augustyniak, M. (2017). Evaluation of oxidative stress biomarkers in Aiolopus thalassinus (Orthoptera: Acrididae) collected from areas polluted by the fertilizer industry. Ecotoxicology, 26(3): 340-350.

Yousef, H.A.; Abdelfattah, E.A. and Augustyniak, M. (2019). Antioxidant enzyme activity in responses to environmentally 


\title{
Effect of different concentrations and application time of vitamin B12 on antioxidant response of Physiophora alceae
}

induced oxidative stress in the 5th instar nymphs of Aiolopus thalassinus (Orthoptera:
Acrididae). Environ. Sci. Pollut. Res., 26(4): 3823-3833.

\author{
تأثير تراكيز مختلفة ووقت تطبيق فيتامين ب 12 على الاستجابة المضادة للأكسة لفيزيوفورا ألكيا

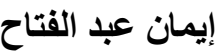 \\ قسم الحشر ات ، كلية العلوم ، جامعة القاهرة ، القاهرة ، مصر \\ eman.alaaeldein@gmail.com
}

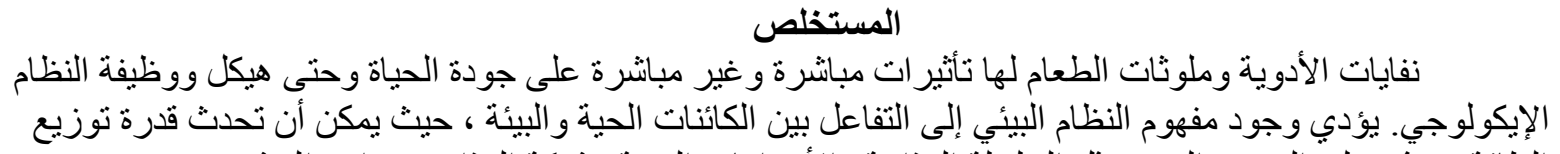

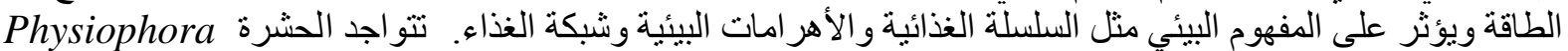
alceae

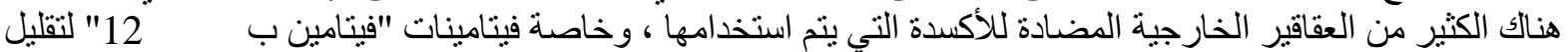

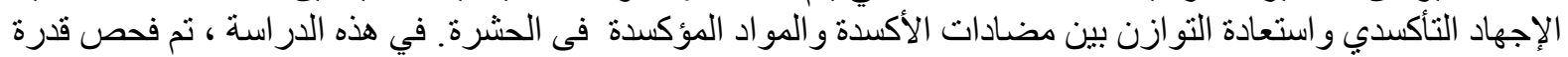

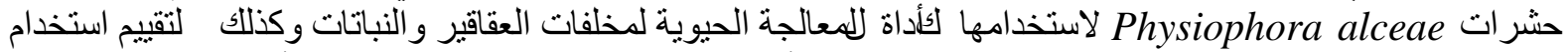
فيتامين B12 في الحشرات البالغة P. alceae للحد من التأثير ات الفسيولوجية لعلامات الإجهاد التأكسدي على التئ الحشرة.

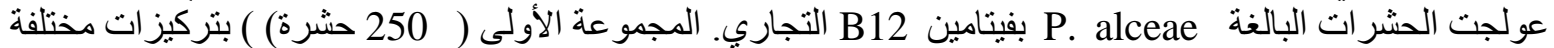

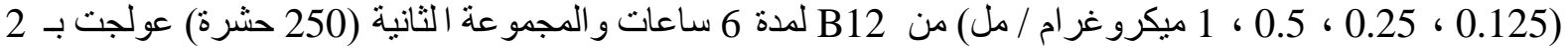

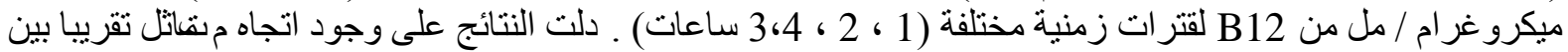

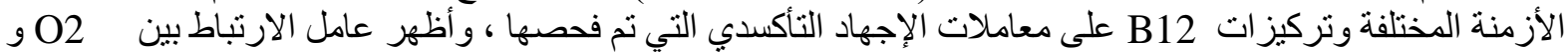

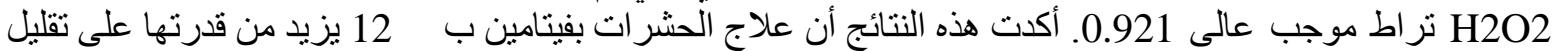

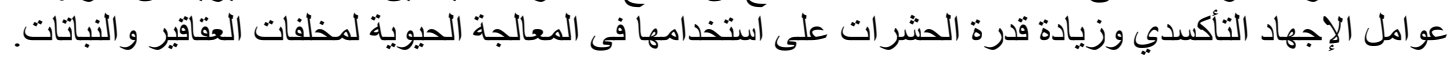

